\title{
Az izraeli szent helyek védelmére vonatkozó biztonsági struktúra bemutatása a vallási közösségek és a rendörség közötti kapcsolattartás kialakításának rendészeti koncepciója vonatkozásában ${ }^{1}$
}

\section{SZABÓ Csaba ${ }^{2}$}

A vallási szélsőségek kutatócsoport kutatási időszakán belül két tanulmány keretében lett kifejtve a keresztény szent helyek védelmi és biztonsági struktúrájának elemzése. Az egyik tanulmány az európai keresztény szent helyeket érintő új típusú biztonsági kihívások elemzését vizsgálta a kritikus infrastruktúraként történő azonosításának érdekében, míg a másik tanulmány a magánbiztonsági szektor szerepét vizsgálta a keresztény szent helyek biztonsági modelljének kialakítása érdekében. A tanulmányokban elsősorban biztonsági, védelmi, magánbiztonsági, valamint rendészeti modellek keretében vizsgálták a felvázolt hipotéziseket a keresztény szent helyek védelme érdekében. Jelen tanulmányban arra keressük a válaszokat, hogy lzrael (amely a legfontosabbnak tartja a szent helyek védelmét), milyen rendészeti módszerek és védelmi modellek alkalmazásával valósítja meg ezen speciális biztonsági előírásokat. Amint az alábbiakban részletesebben kifejtem, az izraeli törvények megkövetelik, hogy az emberek a szent helyeket tiszteletben tartsák, és az izraeli hatóságok tisztában vannak ezekkel a fontos helyszínekkel kapcsolatos társadalmi érzékenység jelentöségével, különösen az egyes vallási közösségek csoportjai közötti eröteljesebben növekvő feszültségek időszakában. Egy olyan országban, ahol a különböző vallások legszentebb helyszínei nagyon közel találhatók egymáshoz földrajzi értelemben, az izraeli rendvédelmi szervek elött álló kihívásokat úgy lehet azonosítani, hogy minden szent helyet és területet egyenlöen kell megvédeni, és egyben lehetóvé tenni az egyén és a vallási közösségek számára, hogy megkülönböztetés nélkül hozzáférhessenek szabadon a béke a közrend és a közbiztonság hatékony fenntartása mellett, egyúttal gyorsan és hatékonyan megszüntetve a felmerülö feszültségeket és törvénysértéseket. Ezek a rendészeti

\footnotetext{
A mű a KÖFOP-2.1.2-VEKOP-15-2016-00001 azonosítószámú, „A jó kormányzást megalapozó közszolgálat-fejlesztés" elnevezésű kiemelt projekt keretében müködtetett Ludovika Kutatócsoport keretében, a Nemzeti Közszolgálati Egyetem felkérésére készült.

2 SZABÓ Csaba dr., PhD, r. őrnagy, tanácsadó. Belügyminisztérium, Rendészeti Vezetőkiválasztási, Vezetőképzési és Továbbképzési Főosztály, Belügyi Szemle, felelős szerkesztő.

Csaba SZABÓ PhD police major

https://orcid.org/0000-0001-9573-2332, szabo.csaba@uni-nke.hu
} 
és katonai jellegü kihivások folyamatos és szakszerü erőfeszítéseket kívánnak a megfelelö társadalmi egyensúly megteremtése érdekében.

Kulcsszavak: izraeli szent helyek, biztonsági stratégia, rendőrség, magánbiztonsági szektor

\section{Jogszabályi alapok az izraeli keresztény szent helyek védelmében}

Az izraeli törvényhozás mint jogalkotó biztosítja az istentiszteletek szabadságát, és egyben biztosítja a keresztény szent helyek védelmét és az azokhoz történő szabad hozzáférést az összes vallási közösség és gyülekezet tagja számára. A szent helyek védelméről szóló 5727-1967 törvény tiltja a szent helyek megalázását vagy más módon történő megrongálását, és egyben biztosítja a különböző vallási közösségek tagjai számára a szabad hozzáférését. A szent helyek ellen elkövetett bűncselekményeket a jogalkotó öt és hét év közötti letöltendő börtönbüntetés kiszabását rendeli. Az 5737-1977 számú büntető törvénykönyv 170. §-a kimondja, hogy a szenthelyek, valamint a vallási közösségek tagjai által látogatott megszentelt épületek megsemmisítése vagy megrongálása az Izrael Állami Jogi Tanácsadó és Jogszabályi Főosztály hatáskörébe tartozik a kivizsgálás vonatkozásában és a cselekmény három év végrehajtásban letöltendő börtönbüntetéssel sújtható. Ezt kiegészítve a 171. § úgy rendelkezik, hogy a vallási istentiszteletek indokolatlan megzavarása, illetve az ott tartózkodó személyek bántalmazása vagy fenyegetése bármilyen formában megvalósul, szintén három év végrehajtásban letöltendő börtönbüntetéssel sújtható a bűncselekményt elkövető személy. ${ }^{3}$

\section{Biztonsági intézkedések az izraeli szent helyek védelme érdekében}

Izrael Állam nagymértékben törekszik arra, hogy valamennyi szent hely és épület védelmét és őrzését a fennálló folyamatos biztonsági kockázat csökkentésével lássa el, valamint (a biztonsági feltételek teljesülése mellett) hogy szabad hozzáférését biztosítson az egyes vallási közösségek számára a keresztény szent helyekre történő bejutáshoz, és egyúttal biztosítottá váljon a szent helyek vonatkozásában, hogy az épületek használata során a keresztény értéküket megőrizzék a társadalom számára. A Belügyminisztérium Szent Helyek Biztonságáért Felelős Főosztálya rendszeres megbeszélést folytat a nem zsidó vallási közösségek tagjaival és a különböző vallási közösségek képviselőivel a vallási események előkészületeivel és végrehajtásával kapcsolatban a szent helyek biztonságának fenntartása érdekében. Tekintettel a Templom-hegy, a Nyugati Fal és a Szent Sír-templom ${ }^{4}$ különösen fontos vallási és turisztikai jelentőségére, egy kü-

Penal Law, 5737-1977.

Benda (2003) 127. 
lönleges rendőri egység felállítását kezdeményezte a belügyminisztérium a kiemelt jelentőségű szent helyek a védelme érdekében. Az izraeli rendőrség (összhangban a szent helyek védelmével, valamint a közrend és közbiztonság fenntartásával kapcsolatban) meghatározott ideig, ideiglenes jelleggel korlátozhatja és megakadályozhatja az egyes kiemelt jelentőségú szent helyek látogathatóságát és megközelíthetőségét. ${ }^{5}$

Izrael súlyos történelmi és folyamatos biztonsági kihívásainak köszönhetően számos olyan biztonsági erőforrás létezik, amelyet a politikai döntéshozók támaszthatnak. Az aktív szolgáltatás tartalékképzéssel, a lakosság többsége minimális katonai kiképzéssel rendelkezik, pozitív következményekkel jár mind a külső katonai képességek, mind a hazai elülső rugalmasság tekintetében. Emellett a magán- és a civil szektorok létfontosságú erőszorzóként szolgálnak Izrael otthoni védelmében. A magán biztonsági őrök és a fegyveres civilek kulcsszerepet játszanak Izrael otthoni védelmében, amennyiben a biztonsági tervezők számukra fontos elemet jelentenek a veszélyértékelések elvégzése során.

\section{Az izraeli rendôrség szervezeti felépítése és speciális rendőri erői}

Az izraeli rendőrség nemzeti rendvédelmi szerv. A területi felosztás vonatkozásában 29 kerületben és 29 alkerületben, valamint további regionális állomásokon 29 ezres állandó létszámmal látják el a törvényben megfogalmazott rendészeti feladatokat. A rendőrség állománya mellett katonai szolgálatot ellátva mintegy 4600 katona lát el rendészeti feladatokat kiemelten a turisztikailag frekventált területeken, közülük mintegy 3300 fő a határőrség szervezetében látja el szolgálatát. Az izraeli rendőrséget a Közbiztonsági Minisztérium felügyeli. Az izraeli rendőrség feladatrendszerének és struktúrájának sajátossága, hogy az állami felügyelet mellett a helyi önkormányzatok, valamint a regionális vezetők is részt vesznek a döntéshozatali folyamatokban, de az irányítás és a szakmai felügyelet egy egységes központi országos parancsnokság fennhatósága alatt marad, amelyet csak az Izraeli Nemzeti Kormányzat felügyel. Az izraeli rendőrség kettős szerepet tölt be az ország biztonsági rendszerében. Az egyik jelentős feladatrendszer a hagyományos bűnüldözési és bűnfelderítési feladatok végrehajtása (kiemelten a közlekedési ügyek és büntetőügyek), még a másik jelentős feladatrendszer, hogy a rendőrség kulcsfontosságú szerepet tölt be Izrael terrorizmusellenes erőfeszítéseinek végrehajtásában. A rendőrségen a szakmai képzések során minden tisztet felkészítenek arra, hogy mind az általános rendőrségi feladatok, mind a terrorizmusellenes feladatokat ellátását képesek legyenek ellátni.

A rendőri erők mellett az izraeli rendőrség három, a terrorizmus elleni küzdelemre szakosodott múveleti egységgel rendelkezik:

- Határrendőrség (Israel Border Police): ${ }^{6}$ Izrael első számú határvédelmi rendészeti szerve. Azokon a határterületeken található zónákban látnak el (elsődlegesen)

\footnotetext{
Israel 2015 International Religious Freedom Report. 12-13.

Argaman (1996) 55-76.
} 
rendészeti feladatokat a szervezet hivatásos állományú tagjai, ahol kiemelt kockázatot jelent Izrael határszakaszainak a támadása. Ezek a határterületek elsődlegesen Ciszjordánia és Kelet-Jeruzsálem. A határrendőrség tagjait az IDF (Israel Defense Forces - Izraeli Védelmi Erők) képezi ki, mivel egyes különleges katonai missziók során az izraeli hadsereg szervezeti rendszerébe integrálódnak, azonban mindvégig a rendőrség általános parancsnoksága alatt maradnak. ${ }^{7}$

- Speciális Járőrszolgálat (Yasam): Az izraeli rendőrség különleges egységei, amelyeket különleges fegyverek és rendészeti taktikák alkalmazásával az Izrael Állam területét érintő, vagy azt veszélyeztető terrorcselekmények során vetnek be. Mindezek mellett szerepet játszanak a közterületeken kibontakozó egyes csoportosan elkövetett erőszakos cselekmények kezelésében és felszámolásában is. ${ }^{8}$

- Különleges rendöri egység (Yamam): Az izraeli rendőrség különleges egysége, amely az alábbi három kulcsfontosságú területre szakosodott: az ellenséges létesítmények, a túszejtett helyzetek és a súlyos bűncselekmények felderítése és a terrorcselekményeket elkövető személyek elfogása vagy ártalmatlanítása, ideértve a fegyverekkel és a kábítószer-csempészettel kapcsolatos bűncselekményeket is. A Yamam képes túszmentési múveletek végrehajtására, amely támadások elsődlegesen polgári célpontok ellen irányulnak. A Yamam tagjai a rendészeti feladatokon kívül katonai, valamint fedett rendőri munka végrehajtásában is részt vesznek. $^{9}$

\section{Az izraeli rendőrség szervezeti modelljének bemutatása a szent helyek védelme érdekében}

Az izraeli rendőrség a biztonsági körülményeket figyelembe véve, számos olyan biztonsági kihívással szembesül a mindennapos feladatellátás során, amely a folyamatosan változó biztonsági környezetből ered. A biztonság fenntartása érdekében a klasszikus rendészeti modelleket szükséges ötvözni olyan elméleti és gyakorlati megoldásokkal, amelyek segítségével megelőzhetővé vállhatnak az állam területén és a határterületeken elkövetendő terror- és bűncselekmények. Ebben a kontextusban vizsgálva Izrael Állam közbiztonsági és védelmi rendszerét megállapítható, hogy csak egy komplex és hatékony megelőző védelmi rendszer hatékony alkalmazásával lehet érvényesíteni azokat a magas szintű biztonsági elveket, amelyeket mind a kormányzat, mind a lakosság megfogalmazott a biztonság megteremtése és fenntartása érdekében. Ezek a meghatározott biztonsági stratégiai elvek nemcsak a lakókörnyezetre és a közterületekre vonatkoznak, hanem azokra a vallási és szent helyekre is, amelyek mind turisztikai, mind a vallásgyakorlás szempontjából kiemelt célpontokat jelentenek a terrorcselekményeket végrehajtani szándékozó személyek számára. ${ }^{10} \mathrm{~A}$ biztonsági kihívások kezelése érdekében, vala-

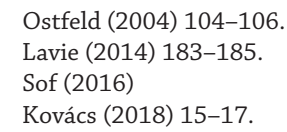


mint Izrael Állam határ- és belterületén gyakori fegyveres konfliktusok következtében megalakításra került a HLHFG-11 ${ }^{11}$ (High Level Home Front Group) védelmi és biztonsági szervezet, amely szervezetben a katonai tapasztalatok figyelembevételével alakították ki a belső biztonság, a közbiztonság, a bűnüldözés, valamint a jogalkotás és a parlamenti ellenőrzés együttes rendszerének múködési struktúráját. ${ }^{12}$

A szervezet kijelölte azokat a fontosabb védelmi témákat, amelyek folyamatos és rendszeres monitorozásával egy egységes strukturális modellt tudnak kialakítani a biztonsági kihívások kezelésére:

- A birósági rendszeren keresztül történő jogorvoslati dinamika gyorsitása és a joggyakorlat hatékonyságának erōsitése.

- A rendörség részérōl a közösség iránti elkötelezettség erôsítésének megteremtése, amelynek középpontjában az Izrael Állam területén élö összes etnikai és vallási közösség bevonása áll - beleértve a társadalomban élö arab és más kisebbségeket is -, amely együttmüködés során célzott közbiztonsági programok kialakitásával és müködtetésével valós és tartós eredményeket lehet elérni a békés közös együttélés érdekében.

- A folyamatos képzés és fejlesztés révén a kiválósági programokban megfogalmazott színvonal iránti elkötelezettség biztositása.

Az Izrael Állam területén található szent helyeket érintő bűn- és terrorcselekmények elkövetésével összefüggésben Micky Rosenfeld főfelügyelő rendőrségi szóvivő megjegyezte, hogy Tel Aviv központjában 70\%-ban bűncselekmények formájában történik a jogsértés, és a maradék, mintegy $30 \%$ a terrorizmusra vonatkozik. A fővárosban, Jeruzsálemben, ezek a számadatok fordított tendenciát mutatnak, ezért Jeruzsálemben kiemelt hangsúlyt fektetnek mind a rendészeti és katonai szervek, mind a kormányzat, mind az egyes nem állami szervezetek a terrorizmus elleni múveletek végrehajtására, kiemelten a vallási és a történelmi helyek védelme érdekében. ${ }^{13} \mathrm{~A}$ biztonsági kockázatok azonosítása kulcsfontosságú szerepet játszik az izraeli rendőrség védelmi struktúrájának kialakításában. Ennek érdekében a rendőrtisztképzést is ennek a biztonsági koncepciónak a megfeleléséhez és hatékony végrehajtásához igazították. A vonatkozó struktúra kimondja, hogy minden izraeli rendőrtisztnek képesnek kell lennie arra, hogy felismerje és kezelni tudja a terrorcselekmények esetén felmerülő helyzetet, annak érdekében, hogy a reakció és a beavatkozási idő minimálisra legyen csökkentve,

11 2015-ben a NATO magas szintű katonai vezetőkből, valamint a NATO és más együttműködő országok tisztviselőiből álló tagjai felhatalmazást kaptak arra, hogy szakmai elemzések formájában foglalkozzanak behatóan a nyugati fejlett társadalmakat érintő háborúk és konfliktusok közvetlen hatásaival, kiemelt figyelmet fordítva azokra a terrorszervezetekre, amelyek figyelmen kívül hagyják a fegyveres konfliktusokra vonatkozó alapvető szabályokat és egyéni harci stratégiájuk alkalmazásával hajtják végre terrorcselekményeiket. Izrael Állam ezeknek a védelmi szakmai elemzések eredményeinek a nemzeti biztonsági és védelmi stratégiába és végrehajtási rendszerbe történő beintegrálásával hozta létre a High Level Home Front Group (HLHFG) szervezetet 2016-ban.

12 Machine (2010) 85-87.

13 Mack (2016) 17-18. Az Emek Shaveh egy olyan izraeli (nem kormányzati) szervezet, amely a kulturális örökséghez való általános jog védelmére törekszik, és egyben törekszik megóvni az ókori helyszíneket az izraeli társadalom és az emberiség számára. A szervezet véleménye szerint az ókori romok az izraeli-palesztin konfliktus politikai eszközeivé váltak, ezért indokolttá vált a fokozott védelem biztosítása mind az állami szervek, mind a nem állami szervek segítségével egyaránt. 
mivel Izrael Állam terrorizmusra vonatkozó tapasztalatai azt mutatják, hogy a gyors és hatékony biztonsági beavatkozás létfontosságú a terrorista incidensek korai szakaszban történő megakadályozásában és felszámolásában. Ennek megfelelően folyamatos továbbképzés tartanak a rendőrtisztek számára a terrorista gyanús személyek felismerése és kiiktatása érdekében, valamint ezzel párhuzamosan minden rendőrkapitányság által foglalkoztatott személynek évente köteles részt vennie az Országos Rendőrfőkapitányság által szervezett antiterrorista képzésen. ${ }^{14} \mathrm{Ez}$ a képzés magában foglalja az összes rendőrségi szolgálati ágra és speciális egységekre vonatkozó terrorizmusellenes tevékenységgel kapcsolatos konkrét követelményeket, beleértve olyan speciális taktikai elemeket, mint a terrorcselekmények valós helyzetben történő szimulációját, a terrorista támadások elemző értékelését, valamint a túszejtő helyzetek gyakorlását olyan speciális létesítményekben és kritikus infrastruktúrákban, mint egyes kiemelt jelentôségû szent helyek, valamint a lakosság ellátása szempontjából kiemelten fontos létesítmények. ${ }^{15}$ A rendőrség állománya számára rendszeres jelleggel biztosított speciális rendészeti képesség kialakításával lehetőség nyílik arra, hogy az izraeli rendőrség azonos időben képes legyen legalább két nagyobb terrorista incidensre reagálni és meghozni a megfelelő biztonsági intézkedéseket a hatékony végrehajtás érdekében. ${ }^{16}$

\section{A vallási közösségek és a rendörség kapcsolatrendszerének helyzete Izraelben}

Az izraeli rendőrség elsősorban a büncselekmények megelőzésére helyezi a hangsúlyt. Ez a megelőzési mechanizmus elsősorban a közterületi jelenlétben, a közösségi közlekedés biztosításában, valamint a lakosság ellátása szempontjából kiemelten fontos kritikus infrastruktúrák védelmében mutatkozik meg. ${ }^{17} \mathrm{Az}$ izraeli rendőrség a biztonsági kihívásokat összetett módon igyekszik kezelni, ezért ezen koncepció mentén a különböző etnikai és vallási közösségek tagjait is bevonják a rendőrség bűnmegelőzési tevékenységébe. ${ }^{18}$ Azonban ezek a rendészeti struktúrák sok esetben kihívásokkal teli tevékenységet jelentenek, mivel az etnikai és vallási közösséggel történő együttmúködés további konfliktusokat generálhat. A rendőrség az etnikai és vallási közösségekkel történő bűnmegelőzési tevékenységre vonatkozó együttmúködés keretében rögzítésre került, hogy a turisztikai-

14 Haberfeld-Hassell (2009) 25-27.

15 Fighting Terror Effectively: An Assessment of Israel's Experience on the Home Front. (2016) 44-55.

16 Chetrit (2015) 33-38. A szerző kifejti tanulmányában, hogy a HLHFG szervezet tagjai egységesen nyilvánultak meg azon állásfoglalás mellett, hogy egyes fontos turisztikai célpontok, határterületek és kiemelt jelentőségủ vallási épületek ellen irányuló támadás esetén törekedni kell a maximális erő alkalmazására, és ezen operatív helyzetekben a szervezet tagjait azonnal és széleskörűen kell tájékoztatni a kialakult helyzetről. A szerző továbbá kifejti tanulmányában, hogy az egyes speciális rendészeti és antiterrorista képzési eljárások során a HLHFG szervezet képviselői megtekintették az Izraeli Országos Rendőrségi Akadémiát, ahol a rendőrségi tisztviselők bemutatták azokat az alapvető szabályokat, valamint valós szimulációs és eljárási rendszereket, amelyeket a valós helyzetekben képesek hatékonyan alkalmazni, például olyan helyzetekben, mint az Izrael Állam állampolgárai, valamint katonái és rendőrei, továbbá a vallási gyülekezetek ellen irányuló öngyilkos merénylók azonosítása és ártalmatlanná tétele, vagy a gépjármúvel elkövetett ramming típusú terrortámadások megakadályozása és a hatékony védekezési rendszer kialakítása.

17 Brown-Benedict (2002) 543-547.

18 Bowling-Phillips (2003) 55-61. 
lag nagyobb jelentőségű szent helyek és a vallási tevékenységek központjának számító, nagyobb tömegeket vonzó épületek esetében kiemelt figyelmet szentelnek ezeknek a létesítményeknek a védelmére. ${ }^{19}$

Az izraeli rendörség stratégiai intézkedései a vallási közösségekkel történö együttmüködés kialakítása érdekében:

- Az izraeli rendőrség nagy jelentőséget tulajdonít a közösségi kapcsolatoknak a társadalom minden ágazatával szemben, kiemelten a vallási közösségekkel.

- Az izraeli rendőrség egy stratégiai tervet hozott létre annak érdekében, hogy javítsa a kisebbségek és a különböző vallási közösségek közti konfliktusok kialakulásának esélyét, különösen a muzulmán arab közösségek viszonylatában.

- Az izraeli rendőrség széles körű társadalmi szerepvállalásra törekszik annak érdekében, hogy az egyes kiemelt jogsértések (közterületi bűncselekmények, terrorcselekmények) problémáinak kezelésére, olyan megoldásokat dolgozzanak ki, amelyek alkalmazásával hatékonyan tudják kezelni a közrendet és a közbiztonságot veszélyeztető közterületi bűncselekményeket. Az izraeli rendőrség képzési struktúrájában megtalálhatók azok az elemek, amelyek segítségével a rendőri intézkedések során a rendőrök képessé válnak felismerni és kezelni az egyes vallási közösségek problémáit. Az izraeli rendőrség vezetői kiemelt figyelmet fordítanak arra, hogy egyes fokozott veszélyhelyzetet követően, amely Izrael Állam területén kialakul a további konfliktushelyzetek megelőzése érdekében rendőrségi tisztségviselőket küldenek az adott területre, hogy előmozdítsák a kölcsönös párbeszédet a helyi közösségi és vallási vezetőkkel. ${ }^{20}$ Ennek a párbeszédnek a kialakítása egy évekig tartó intenzív kapcsolatépítés eredménye, amely egyértelműen bizonyítja azt, hogy az izraeli rendőrség élvezi - bizonyos - vallási közösségek bizalmát a bűnfelderítés és a kölcsönös információáramlás vonatkozásában. Megemlítendő, hogy számos kezdeményezés és rendészeti program folyik ezen kapcsolatok továbbfejlesztése érdekében.

- Például a jeruzsálemi körzeti rendőrség újjászervezte a területi régiók határait, hogy hatékonyan tudjon segítséget nyújtani az egy körzeten belül élő keresztény, arab, valamint ortodox zsidó családok számára, ezáltal is erôsítve a vallási közösségek iránti elköteleződésének politikáját, valamint hogy az egyes vallási közösségek részéről felmerülő specifikus igényekhez igazítsa az alkalmazott rendészeti struktúrát, beleértve a megfelelő háttérrel rendelkező rendőrtiszteknek a kiképzését a hatékony kapcsolatfelvétel kialakítása érdekében. ${ }^{21}$

19 Antonopoulos (2003) 45-49.

20 Clancy et al. (2001) 25-48. A szerző tanulmányában rámutat arra, hogy a jeruzsálemi rendőrség a helyi óváros muszlim és keresztény negyedeiben folytatott terrorellenes rendőrségi ellenőrzések során - amelyeket elsősorban a '90-es évek második felének időszakára vonatkozó terrorhullám miatt hajtottak végre -, már abban az időszakban kiemelt figyelmet fordítottak arra, hogy a helyi vallási közösségek vezetőinek előzetes tájékoztatását követően vizsgálják át az adott területet.

21 Israel 2016 International Religious Freedom Report. United States Department of State. Bureau of Democracy, Human Rights, and Labor. 19-22. 
Az izraeli rendőrség egy nagy jelentőségű toborzási kísérletet indított az arab vallású izraeli állampolgárok számára a rendőrség hivatásos állományába történő belépés elősegítése érdekében. Az izraeli kormányzat arra törekszik, hogy további 3000 fő muszlim vallású tisztet vegyen fel az elkövetkező három évben a rendőrség állományába, ezzel megduplázva a nem zsidó vallású személyek részvételét a rendőrségen belül. ${ }^{22}$ Az izraeli rendőrség országos vezetője 2016-ban kinevezte az első muszlim vallású főparancsnokot a rendőrség regionális vezetőjének, akinek a legfőbb feladata, hogy húsz rendőrségi tisztviselővel egy új és hatékony rendészeti struktúrát dolgozzon ki kifejezetten a muszlim vallású közösségekkel való együttmúködés további javításának előmozdítása érdekében. ${ }^{23}$ Ezeket a jelentős változásokat és átalakításokat egy ötéves stratégiai terv keretében hajtották végre az izraeli rendőrségen belül, amelyet az izraeli rendőrség az izraeli-arab közösségekkel való kapcsolattartás elősegítése és fejlesztése érdekében kezdeményezett, és amellyel jelentős javulást kívánnak elérni a közrend a közbiztonság, valamint és a terrorcselekmények megakadályozása érdekében. Az izraeli rendőrség az országos munkaerő-toborzás mellett egy másik meghatározó stratégiai tervet is előterjesztett a jeruzsálemi rendőrségi állományra vonatkozó feladatrendszer átalakítására vonatkozóan, amely elsősorban Jeruzsálemben elkövetett bűncselekmények felderítési tevékenységére fog összpontosítani. A rendőrség által kidolgozott terv célja, hogy kiemelt jelentőséget fordít a bűnözés akut problémájára Jeruzsálem arab szektorában, amely elsődleges az illegális lőfegyver- és lőszerbirtoklás magas arányának a megszüntetésére törekszik. A rendőrség a feladatrendszer tervezetéről szóló elemzésében megjegyzi, hogy az arab közvélemény pozitívan fogadta, és így vesz részt a rendőrséggel együttmüködve a terv végrehajtásában, felismerve, hogy sürgősen szükség van alapvető változásokra, és ezek a változások csak a jeruzsálemi városi rendőrséggel való együttműködés révén érhető el. ${ }^{24}$

A jeruzsálemi rendőrség az elmúlt évtizedben fokozatosan kialakuló jelentős létszámhiánnyal szembesült, elsősorban a közterületi szolgálatot ellátó állomány vonatkozásában. A létszámhiánnyal összefüggésben Jeruzsálemben kialakultak olyan területek, ahol jelentősen csökkent a rendőrség közterületi jelenléte. Az arab közösségek aggodalmukat fejezték ki 2018 elején a jeruzsálemi rendőrség vezetője részére, hogy a rendőrségen belül tapasztalható létszámhiány kerüljön orvoslásra és egyúttal azokon a területeken is növeljék a közterületi órák számát a rendőrség vonatkozásában, ahol korábban ez nem volt lehetséges. ${ }^{25} \mathrm{Az}$ arab vallási vezetők továbbá kifejtették azon álláspontjukat, amelyben megfogalmazták, hogy az izraeli társadalomban az arab

\footnotetext{
Hadid (2016)

Gontarz (2017)

24 Cashman (2017) A szerző kifejti, hogy helyi önkormányzati vezetők, valamint az arab közösségek vezetői azt szeretnék elérni, hogy egész Izrael Âllam területén - ugyanúgy a városokban, mint a falvakban - a rendőrség tegyen meg mindent a bűn- és terrorcselekmények, valamint a közterületeken elkövetett erőszakos cselekmények csökkentése érdekében.

25 Breiner-Khoury (2018) A cikk kifejti, hogy az elvégzett kutatás részeként tizenegy rendőrparancsnokkal (anonim módon) készítettek interjút, elsősorban azokban az izraeli városokban, ahol többségben vannak az arab közösségek tagjai, valamint néhány vegyes társadalmi összetételű városokban. Kelet-Jeruzsálemben három rendőrkapitányság parancsnokát is megkérdezték a kutatás során.
} 
közösség tagjai ellen elkövetett bűncselekmények magas száma, valamint az egyéni biztonságérzet hiánya nem új probléma. A közelmúltban végzett kutatások alapján - amelyek az adott arab közösségekre vonatkozó közbiztonsági helyzetet több oldalról vizsgálták - megállapításra került, hogy az arab közösségek nem csak a kialakult rendőri létszám hiányában látják az alapvető közbiztonsági problémákat. A rendőri személyi állomány hiánya csak az egyik lényeges szempont a biztonsági problémák kialakulásában. Az arab közösségek vezetői többek között a magas búnözési arányokban, a panaszosokkal történő együttmúködés hiányában, valamint a jogsértések során keletkező bizonyítékok eltitkolásában látják a problémákat.

A kutatás során megkérdezett rendőrparancsnokok az alábbi válaszokat adták a feltett kérdésekre:

- Jelentős mértékben növekszik az arab közösségekben a bűnelkövetések száma.

- Az illetékes minisztériumok elhanyagolják az arab közösségeket a finanszírozás és az erőforrások szétosztása tekintetében.

- A lakosság vonatkozásában a rendőrség nem csupán szolgáltatásokat nyújt az adott közösségeknek. A rendőrséget a lakosság elsősorban az izraeli-palesztin konfliktus prizmáján keresztül ítéli meg. A rendőri intézkedéseket a zsidó vallási vezetők is bírálják, mivel sérelmezik, hogy számos esetben a rendőri intézkedések nem védik kellő mértékben a zsidó vallású embereket. Ezért a rendőrök ütközőként funkcionálnak a zsidó és az arab közösségek között, amelynek következménye, hogy a rendőrök jelentős veszélynek vannak kitéve az adott vegyes társadalmi körzetekben. ${ }^{26}$

Fontos szempont a vallási közösségekkel történő rendőrségi együttmúködésben, hogy a közösség tagjainak a beilleszkedése a rendőrség soraiba gyors és hatékony legyen, hogy ezáltal képessé váljanak és egyben felkészülhessenek az adott közigazgatási területen történő rendészeti munka elvégzésére. Az ilyen egyéni és szervezeti erőfeszítések hatása, hogy egy erkölcsi kört hoznak létre, ami azt jelenti, hogy a közösségi rendőrség egyre inkább beilleszkedik a vallási közösségek életébe. Ennek a társadalmi beavatkozásnak a következménye, hogy lehetővé válik a biztonságérzet növelése és az erőszakos tevékenységek csökkentése. ${ }^{27}$ A következő fejezetben bemutatom azokat az izraeli szent helyeket, amelyeknek a védelme és biztosítása kiemelt jelentőséget képvisel a rendőrség stratégiai rendszerében.

\footnotetext{
26 Az Izraeli Knesset Kutatóközpont jelentése szerint (összhangban a rendőrségi adatokkal) 2014 és 2016 között az erőszakos büncselekmények $64 \%$ az arab közösségekben követték el, annak ellenére az arab közösségek csupán Izrael népességének mintegy $20 \%$ teszik ki. Ez az adat azt mutatja, hogy 100 emberre jutó emberölések száma a zsidó személyek ellen elkövetett gyilkosságok áldozatainak ötszöröse. A kutatóközpont jelentése rámutat arra, hogy amennyiben ilyen jelentőségú eltérések mutatkoznak a továbbiakban is a bủncselekmény mértékében, akkor abban az esetben a rendőrség nem tudja betölteni a vákuum és az ütköző szerepét a jelenlegi erőivel és eszközeivel. A változásnak a vallási közösségeken belülről kell erednie és nem csak a rendőrségnek kell törekedni a jogszabályok betartására.

27 Kovács (2017) 17.
} 


\section{A Templom-hegy rendészeti biztosítása}

$\mathrm{Az}$ építmény az iszlám hívőinek az egyik legfontosabb szent helye. Izrael Állam tiszteletben tartja a Waqf (Iszlám Vallási Alapitvány Hatósága) fennhatóságát a Templomhegy felett, amely szervezet tagjai a Templom-hegy vallási vezetését felügyelő tisztviselők. Általános szabályként elfogadott, hogy az izraeli hatóságok nem zavarják a Waqf tevékenységét, és nem eszközölnek korlátozásokat azokkal a muzulmánokkal szemben, akik imádkozni akarnak a Templom-hegynél, mindaddig amíg legálisan lépnek be Izrael Állam területére. Amennyiben a rendőrség a belső hírszerzési információk és a biztonsági kockázatok alapján magas szintű kockázatúnak ítélik meg a közbiztonságra nézve az adott szent helyet, akkor abban az esetben a rendőrség korlátozhatja a Jogi Tanácsadó és Jogszabályi Osztályon keresztül a napi imádságok számát a szent hely védelme, továbbá a közrend és a közbiztonság fenntartása érdekében. Az ilyen nagy horderejú rendőrségi intézkedés meghozatalára vonatkozó döntés esetében alaposan mérlegelik az összes körülményt, valamint elemzik a rendelkezésre álló releváns adatokat. A kialakított rendőrségi gyakorlat hatékonynak bizonyult a terrorcselekmények megelőzésében a szent helyek érdekében. Megjegyzendő, hogy az időszakosan életbe léptetett korlátozások mellett az izraeli rendőrség (meghatározott időben és biztosítás mellett) biztosítja a Templom-hegyhez történő eljutást a vallásukat gyakorolni kívánó személyek számára. Így biztosítják a vallásszabadsághoz való alapvető jogot. ${ }^{28}$

Ciszjordánia esetében eltérő rendelkezéseket találunk a vallásgyakorlás vonatkozásában. A Ciszjordániában élő lakosoknak, akik nem rendelkeznek érvényes és állandó belépési vízummal vagy engedéllyel Izrael Állam területére, a rendőrség (a vonatkozó jogszabályok értelmében) megtiltja, hogy az Izrael Állam területén található szent helyeket látogathassák. Mindazonáltal Izrael Állam lehetővé teszi a Ciszjordániában élő muzulmánoknak, hogy akik érvényes belépési engedéllyel rendelkeznek Izrael Állam területére, azok szabadon látogathassák és gyakorolhassák vallásukat a Templom-hegy területén. Éves szinten tízezrek lépnek be a Waqf által felügyelt kapun, hogy gyakorolják hitüket a szent helyeknél Izraelben. ${ }^{29}$

A Templom-hegy turisztikai jelentôsége is jelentôs. 2014-ben 235637 turista és 11754 izraeli állampolgár látogatta meg a templomot a Mughrabi kapun keresztül. Ezek közül 7483 turista és 1386 izraeli állampolgár látogatta meg a templomot az adott júniusi és júliusi hónapokban, annak ellenére, hogy Izrael katonai múveletet hajtott végre terrorista infrastruktúrák ellen Gázában és a Ciszjordániában. Meg kell jegyezni ebben az összefüggésben, hogy a Templom-hegy továbbra is nyitva áll, és elérhető volt a júniusi és júliusi nagyobb turisztikai időszakban, annak ellenére, hogy számos erőszakos zavargás tört ki több helyen, többek között a Templom-hegy területén is. 2017 júliusában a szent helyet több napra zárva tartotta a rendőrség, miután három izraeli-arab terrorista tü-

28 The Legal Counseling and Legislation Department (International Law). State of Israel Ministry of Justice.

29 Meg kell jegyezni, hogy a Templom-hegy mint meghatározó történelmi zsidó templom, amelyet több ezer évvel ezelőtt állítottak, a zsidó vallás legszentebb helyszíneinek egyike. Ennek ellenére a zsidó vallású személyek kizárásra kerülnek a templomban való imádkozástól, annak ellenére, hogy a templom kiemelt fontossággal bír a zsidó vallásban. 
zet nyitott egy csapat rendőrre, és megölt közülük kettőt. A terroristák a támadás előtt rejtették el a fegyvereket a Templom-hegy területén. Közel ötven év után ez volt az első alkalom, hogy Izrael Állam pénteken, az iszlám szent napján, lezárta a teljes területet. Vasárnap délben Izrael újból megnyitotta a Templom-hegy egyik bejáratát Jeruzsálem minden muzulmán lakója előtt, kortól vagy nemtől függetlenül. Azonban fémdetektorokat helyeztek el a kapunál, amelyeket Izrael a múltban már felállított, majd később eltávolították őket. A Templom-hegy vallási vezetését felügyelő Waqf-tisztviselők nem voltak hajlandók belépni a Templom-hegyre, és tüntetésbe kezdtek a hívőkkel a bejáratnál, akik a kapu mellett végezték délutáni imájukat. A rendőrség a kialakult helyzet kezelése érdekében biztosította a Waqf tisztségviselőit, hogy nekik nem kell áthaladni a fémdetektoros kapukon. ${ }^{30}$

\section{Összefoglalás}

A tanulmányban ismertettem az izraeli szent helyek védelmére vonatkozó biztonsági struktúrát, valamint a zsidó és a muszlim vallási közösségek és a rendőrség között kialakított kapcsolattartás rendszerének rendészeti koncepcióját. A tanulmány rávilágított arra, hogy az izraeli szent helyeket fenyegető bűn- és terrorcselekmények megakadályozása, valamint a fenyegetések megelőzése érdekében milyen rendőrségi módszertant alakítottak ki. A rendőrségi módszertan elemzése során megvizsgáltam az izraeli szent helyek rendészeti rendszerelemeinek teljeskörűségét, valamint a valós biztonsági kockázattal arányos kiépítettségének jelenlegi helyzetét. Az elmúlt években az izraeli rendőrség és a belügyminisztérium több programot indított az arab szektorban a rendőrségi kapcsolatok elmélyítése érdekében, valamint a bünelkövetés csökkentése és az egyéni biztonságérzet erősítése, továbbá a rendőrségbe és a jogállamiságba vetett bizalom elősegítése érdekében. A rendőrség a szent helyek ellen elkövetett bűnelkövetés megelőzése érdekében különböző, elsősorban a kapcsolatépítésre és a kommunikációs csatornák kiszélesítésre helyezve a hangsúlyt dolgozott ki programokat elsősorban az arab vallási vezetőkkel történő kapcsolattartás érdekében. A rendőrség nagy hangsúlyt fektetett az arab rendőrök toborzására, amely eredményeként a rendőrségben szolgálatot teljesítő muszlimok száma folyamatosan emelkedett az elmúlt évek során. Az izraeli rendőrség a szent helyek védelme érdekében több esetben korlátozta a megközelítést, mind a turisták, mind a hívek vonatkozásában.

\footnotetext{
30 Izrael megnyitotta a Templom-hegyet, a hívek tüntettek a fémdetektorok miatt. 2017. 07. 16. Forrás: https://ujkelet. live/2017/07/16/izrael-megnyitotta-a-templom-hegyet-a-hivek-tuntettek-a-femdetektorok-miatt/ (2018. 07. 17.)
} 


\section{IRODALOMJEGYZÉK}

Antonopoulos, Georgios (2003): Ethnic and Racial Minorities and the Police: A Review of the Literature. Police Journal, Vol. 76, No. 3.

Argaman, Yosef (1996): The Border - Cases in the History of the Border Police. In: Israel: The Border Police, the Green Berets Association and the Ministry of Defense Publication.

Benda Iván (2003): Az élő Jeruzsálem. Budapest, Szabad Föld Könyvkiadó.

Bowling, Ben - Phillips, Coretta (2003): Policing Ethnic Minority Communities. In Newburn, Tim eds.: Handbook of Policing. Devon, Collumpton.

Breiner, Josh - Khoury, Jack (2018): Crime Is Rampant in Arab Israeli Communities, but Police Lack the Resources to Bring About Change. Israel News. 2018. 04. 08.

Brown, Ben - Benedict, Wm Reed (2002): Perceptions of the Police: Past Findings. Methodological Issues, Conceptual Issues, and Policy Implications. Policing, Vol. 25, No. 3. 543-580.

Cashman, Greer Fay (2017): Local Council Leaders of Arab Communities Urge Police to Quell Violence. 2017. 08. 02. Forrás: www.jpost.com/Israel-News/Local-council-leaders-of-Arab-communitiesurge-police-to-quell-violence-501459 (2018. 07. 15.)

Chetrit, Shlomi (2015): Researching the Past, Looking to the Future: The Israel Police History Department. Spotlight on Special Units, No. 10.

Clancy, Anna - Hough, Mike - Aust, Rebecca - Kershaw, Chris (2001): Crime, Policing, and Justice: The Experience of Ethnic Minorities. Home Office Research Study 223. London, Home Office.

Fighting Terror Effectively: An Assessment of Israel's Experience on the Home Front. (2016) High Level Home Front Group.

Gontarz, Nir (2017): What Israel's First and Only Muslim Police General Had to Say About the Temple Mount Attack. Israel News. 2017. 07. 19.

Haberfeld, M. R. - von Hassell, Agostino (2009): Proper Proactive Training to Terrorist Presence and Operations in Friendly Urban Environments. In: NATO Security through Science Series: Human and Societal Dynamics, Vol. 21.

Hadid, Diaa (2016): Israel Seeking Police Recruits: Eager, and Arab. The New York Times. 2016. 09. 03. Forrás: www.nytimes.com/2016/09/04/world/middleeast/israeli-police-recruiting-arabs-to-jointhe-force-not-resist-it.html (2018. 07. 10.)

Kovács István (2018): Prostitúció, és prohibíció a mai Magyarországon, avagy miért nem sikerül a rendőrségnek a szocializmust levetkőznie a XXI. században?. Létünk (Újvidék), 2. sz. 15-17.

Kovács, István (2017): Is the prostitution a threat/danger to a country's (national) security?. National Security Review: Periodical of The Military National Security Service 2017, különszám. 12-24.

Lavie, Smadar (2014): Wrapped in the Flag of Israel. London, University of Nebraska Press.

Machine, Garret (2010): Israeli Security Concepts: A Comprehensive Guide For Selecting Training And Deploying A Security Team For Installation And Personnel Protection. CreateSpace Independent Publishing Platform.

Mack, Eitay (2016): Selectively Sacred: Holy Sites in Jerusalem and its Environs. Emek Shaveh.

Ostfeld, Zehava (2004): An Army is Born. Vol. 1. Israel Ministry of Defense.

Sof, Eric (2016): YAMAM - Special unit of Israel Border Police. Spec Ops Magazine. 2016. 12. 28. Forrás: https://special-ops.org/sof/unit/yamam-special-unit-of-israel-border-police/ (2018. 07. 10.)

\section{Jogforrások}

Israel 2016 International Religious Freedom Report. United States Department of State. Bureau of Democracy, Human Rights, and Labor.

The Legal Counseling and Legislation Department (International Law). State of Israel Ministry of Justice. Forrás:https://tbinternet.ohchr.org/Treaties/CAT/Shared\%20Documents/ISR/INT_CAT_AIS_ISR_23830_E.pdf (2015. 01.30.)

Penal Law, 5737-1977. 


\section{Internetes forrás}

Izrael megnyitotta a Templom-hegyet, a hívek tüntettek a fémdetektorok miatt. 2017. 07. 16. Forrás: https://ujkelet.live/2017/07/16/izrael-megnyitotta-a-templom-hegyet-a-hivek-tuntettek-afemdetektorok-miatt/ (2018. 07. 17.)

\section{ABSTRACT \\ Presentation of the Security Structure for the Protection of the Sacred Sites of Israel in the Context of the Concept of Policing, the Development of Relations between Religious Communities and the Police}

SZABÓ Csaba

Within the research period of the Research Group on Religious Extremities, an analysis of the defence and security structure of Christian sacred sites was presented in two studies. One study examined the analysis of the new security challenges facing the European Christian holy sites in order to identify critical infrastructure, yet another study examined the role of the private security sector in order to develop the Christian holy sites security model. In the studies, the hypotheses outlined for the protection of Christian holy sites are examined primarily in the framework of security, defence, private security and law enforcement models. In this paper, we are looking for answers to the question of how Israel (which considers the protection of sacred places as the most important) is to implement these special security standards through the use of policing methods and protection models. As explained in more details below, Israeli law requires people to respect holy places, and the Israeli authorities are aware of the importance of social sensitivity to these important places, especially during periods of increasing tension between groups of religious communities. In a country where the most sacred places of different religious are very close to each other geographically, the challenges faced by Israeli law enforcements agencies can be identified by defending all sacred sites and territories equally and allowing individuals and religious communities to be protected; to have free access without discrimination, the effective maintenance of peace, public order and security, while rapidly and effectively eliminating tensions and violations of law. These law enforcement and military challenges require continuous and professional efforts to achieve the right social balance.

Keywords: Israeli holy places, security strategy, police, private security sector 